\title{
Different Methods of Soil DNA Extraction
}

Asmita Kamble and Harinder Singh*

Department of Biological Sciences, Sunandan Divatia School of Science, NMIMS Deemed to be University, Mumbai, India

*For correspondence: $\underline{\text { Harinder.Singh@nmims.edu }}$

[Abstract] Soil is the major reservoir of microbial diversity. Only $1 \%$ of microbial diversity can be cultured while $99 \%$ is still not culturable. It is necessary to extract DNA from soil in order to explore the $99 \%$ microbial diversity, which will be useful to harness novel industrial enzymes and natural products. In the present study, six traditional and two kit-based methods were utilized to obtain total soil DNA from Garden soil. Quality (Absorbance ratio at $A_{260} / A_{230}, A_{260} / A_{280} n m$ ) of the extracted DNA was assessed and quantity was analyzed using the BioTek Epoch Microplate spectrophotometer. Quality of DNA is one of the important factors that should be taken in to account for downstream applications such as PCR or cloning experiments.

Keywords: Soil DNA, Non-culturable, DNA extraction, Garden soil

[Background] Soil is the largest terrestrial reservoir of microbial bio-diversity which significantly balance the critical cycle of carbon, nitrogen, and phosphorous; along with maintaining plant health, structure and fertility of the soil. $1 \mathrm{~g}$ of soil harbors 1,00,000-10,00,000 different bacterial and archaeal species (Satyanarayana, 2017). However, only $1 \%$ of the microbial communities can be cultured in the laboratory conditions while $99 \%$ are still unexplored because they are non-culturable. Total soil DNA extraction potentially onsets the journey of revealing hidden microbial diversity (Robe et al., 2003; Fatima et al., 2011 and 2014; Lamizadeh et al., 2019).

Soil DNA extraction includes two major steps: microbial cell lysis followed by purification to get rid of inhibitory molecules of humic acid and fulvic acid. Cell lysis can be performed via physical, mechanical and chemical approaches; or a combination of all three methods. These methods involve the use of detergents such as Sodium Dodecyl Sulfate (SDS) along with heat treatment in buffers like Tris- $\mathrm{HCl}$ or sodium phosphate buffers, along with the introduction of chelating agents such Ethylenediaminetetraacetic acid (EDTA) to protect extracted DNA from DNases which are readily present in external environment. There are different components which add to the effectiveness of cell disruption such as enzymatic treatment with lysozyme, using strong chaotropic agents such as guanidium salts, physical and mechanical treatment such as using liquid nitrogen to grind soil samples, ultra-sonication, glass beads, Zirconia beads and bead-beating approach for cell lysis. Various combinations of these methods are utilized to improve the yield of isolated DNA. Purification steps are conducted after DNA extraction with the help of phenol:chloroform:isoamyl-alcohol method (PCI method), ethanol precipitation, precipitation via polyethylene glycol, isopropyl alcohol, and spin columns. Purification is a crucial step as it involves the removal of PCR and restriction digestion 
inhibitors such as humic and fulvic acid which are co-extracted along with DNA. Hence, effective extraction procedure followed by stringent purification are crucial steps for isolating DNA which can be used for better understanding of microbial biodiversity (Fatima et al., 2011; Bag et al., 2016).

The present study was aimed to obtain a high yield of total soil DNA from garden soil by using different conventional methods of extraction as well as soil DNA kits (HiPura soil DNA kit and Dneasy power soil DNA kit). A comparative analysis was performed in terms of purity and yield using BioTek Epoch Microplate spectrophotometer for absorbance measurements.

\section{Materials and Reagents}

A. For soil collection and processing

1. Sterile $50 \mathrm{ml}$ Falcon (Tarson, catalog number: 546041)

2. Sterile scapula

3. Garden soil

4. Ethanol

5. Liquid Nitrogen

B. For Extraction of total soil DNA by different methods

1. $0.1 \mathrm{~mm}$ Zirconia beads (BioSpec, catalog number: NC0362415)

2. $2.7 \mathrm{~mm}$ Glass beads (BioSpec, catalog number: 11079127)

3. $50 \mathrm{ml}$ sterile Falcon (Tarson, catalog number: 546041 )

4. $2 \mathrm{ml}$ Eppendorf (Tarson, catalog number: 500020)

5. $1.5 \mathrm{ml}$ Microcentrifuge tube (Tarson, catalog number: 5000010 )

6. Filter $0.45 \mu \mathrm{m}$ (Jsil)

7. $1,000 \mu \mathrm{l}$ Microtips (Tarson, catalog number: 5210010 )

8. $200 \mu \mathrm{l}$ Microtips (Tarson, catalog number: 521020)

9. Disodium Hydrogen Phosphate anhydrous $\left(\mathrm{Na}_{2} \mathrm{HPO}_{4}\right)$ (Molychem, catalog number: QB4Q640403)

10. Sodium Dodecyl Sulfate (SDS, $\mathrm{CH}_{3}\left(\mathrm{CH}_{2}\right){ }_{11} \mathrm{OSO}_{3} \mathrm{Na}$ ) (Affymetrix, catalog number: 18220)

11. Polyvinylpyrrolidone [PVPP, $\left.\left(\mathrm{C}_{6} \mathrm{H}_{9} \mathrm{NO}\right) \mathrm{n}\right]$ (Amresco, catalog number: 0507)

12. Sodium Chloride ( $\mathrm{NaCl}$, Fisher Scientific, catalog number: 27605)

13. Chloroform $\left(\mathrm{CHCl}_{3}\right)$ (Molychem, catalog number: 13620)

14. Sodium acetate trihydrate $\left(\mathrm{CH}_{3} \mathrm{COONa} \cdot 3 \mathrm{H}_{2} \mathrm{O}\right)$ (Fisher Scientific, catalog number: $\left.1390 \mathrm{M}\right)$

15. Tris (Hydroxymethyl)Aminomethane Hydrochloride (Tris- $\left.\mathrm{HCl}, \mathrm{C}_{4} \mathrm{H}_{11} \mathrm{NO}_{3} . \mathrm{HCl}\right)(\mathrm{SRL}$, catalog number: 99438)

16. Ethylenediaminetetraacetic acid (EDTA, Qualigens, catalog number: 12635)

17. Phenol:Chloroform:Iso-amylalcohol 25:24:1 (PCl) (Sigma, catalog number: P2069)

18. Sodium Dihydrogen orthophosphate Dihydrate $\left(\mathrm{NaH}_{2} \mathrm{PO}_{4} \cdot 2 \mathrm{H}_{2} \mathrm{O}\right)$ (Molychem, catalog number: 25700) 
19. Cetyl trimethylammonium bromide (CTAB) (Molychem, catalog number: 22560)

20. Mannitol (HiMedia, catalog number: RM9914)

21. Lysozyme (Sigma, catalog number: 89833)

22. Proteinase K (Sigma, catalog number: P2308)

23. Sodium Lauroyl Sarcosine (Amersco, catalog number: 0719)

24. Isopropyl alcohol (Molychem, catalog number: 1750)

25. Iso-amyl alcohol (SRL, catalog number: 69931)

26. Guanidine Hydrochloride (Sigma, catalog number: G3272)

27. Glycine (MP Biomedicals, catalog number: 194825)

28. Sodium Hydroxide (Molychem, catalog number: 25800)

29. Polyethylene Glycol (6000) (LOBA, catalog number: Art.5312)

30. Hydrochloric acid (Molychem, catalog number: 23540)

31. RNase (Invitrogen PureLink Genomic DNA mini kit, catalog number: K1820-01)

32. Proteinase K (Invitrogen PureLink Genomic DNA mini kit, catalog number: K1820-01)

33. Spin Column (Invitrogen PureLink Genomic DNA mini kit, catalog number: K1820-01)

34. Wash buffer1 (Invitrogen PureLink Genomic DNA mini kit, catalog number: K1820-01)

35. Wash buffer2 (Invitrogen PureLink Genomic DNA mini kit, catalog number: K1820-01)

36. Elution buffer (Invitrogen PureLink Genomic DNA mini kit, catalog number: K1820-01)

37. Ethanol $99.9 \%$ pure (Changshu Hongsheng Fine Chemicals, catalog number: 1170)

38. Stock solution (see Recipes)

$1 \mathrm{M} \mathrm{NaCl}$

$1 \mathrm{M} \mathrm{NaH}_{2} \mathrm{PO}_{4}$

$1 \mathrm{M} \mathrm{Na}_{2} \mathrm{HPO}_{4}$

$0.2 \mathrm{M} \mathrm{Na}_{2} \mathrm{HPO}_{4}$

$1 \mathrm{M}$ Tris- $\mathrm{HCl}$

0.2 M EDTA

$1 \mathrm{M} \mathrm{HCl}$

50x TAE buffer

39. Working stock solution (see Recipes)

DNA extraction buffer 1

$50 \%$ PEG (6000)

$0.6 \mathrm{M} \mathrm{NaCl}$

Chloroform:Isoamyl alcohol (24:1)

$3 \mathrm{M}$ sodium acetate

$\mathrm{T}_{10} \mathrm{E}_{1}$ buffer

$\mathrm{PCl}$

0.1 M Phosphate buffer saline

DNA extraction buffer 2

$10 \% \mathrm{CTAB}+0.7 \mathrm{M} \mathrm{NaCl}$ 
TEN buffer ( $\mathrm{pH}$ 8.0)

TEN buffers ( $1 \mathrm{ml}$ ) supplied with $0.2 \mathrm{mg}$ Lysozyme

$20 \%$ SDS

$\mathrm{T}_{50} \mathrm{E}_{1}$

Lysozyme $(10 \mathrm{mg} / \mathrm{ml})$

Guanidine- $\mathrm{HCl}(5 \mathrm{M})$

10\% Sodium Lauryl Sarcosine

TENP

Lysozyme solution

SDS solution

1x TAE buffer

$70 \%$ Ethanol

C. Commercial kits for soil DNA extraction

1. HiPurA soil DNA kit (HiMedia, catalog number: MB542)

2. Dneasy Power Soil (Qiagen, catalog number: 12888-50)

D. For agarose gel electrophoresis

1. Tris-Base (MP Biomedicals, catalog number: 103133)

2. EDTA (Qualigens, catalog number: 12635)

3. Glacial Acetic acid (Molychem, catalog number: 21020)

4. Ethidium bromide (Sigma-Aldrich, catalog number: E7637)

5. 1 kbp ladder (Generuler, catalog number: SM0313)

6. 6x gel Loading dye (Frementas, catalog number: R0611)

7. Agarose (MP Biomedicals, catalog number: 218072090)

\section{Equipment}

1. Sieve (Mesh size of $0.22 \mathrm{~mm}$, Sumeet Royal Interchangeable sieve)

2. Mortar and pestle (diameter of Mortar: $6 \mathrm{~cm}$ )

3. Pipettes $100-1,000 \mu \mathrm{l}, 20-200 \mu \mathrm{l}, 0.5-10 \mu \mathrm{l}, 2-20 \mu \mathrm{l}$ (Glison)

4. Water bath (Metalab, model: MSI14)

5. Centrifuge (Eppendrof, model: $5424 \mathrm{R}$ )

6. Micro-centrifuge (Pfact, model: $5804 \mathrm{~K}$ )

7. Incubator Shaker (Hexatech, model: HIPL-035C)

8. Ice-machine (Wensar, model: LMIF series)

9. $-20^{\circ} \mathrm{C}$ refrigerator (Thermo)

10. Refrigerator (LG, model: GL-365YVQG5)

11. Sonicator (Cole-Parmer, model: 08895-22) 
12. Weighing machine (Shimadzu, model: AUX220)

13. Horizontal gel electrophoresis apparatus (Techno Source, model: Sleek Gel)

14. Gel Documentation system (Bio-Rad, model: Universal Hood II)

15. Epoch Microplate spectrophotometer with Take3 plate accessories (BioTek, serial No.: 401554)

16. Microwave (LG microwave, model: MS-2347BS)

\section{Software}

1. Gen-5 Data Analysis Software (version 3.03)

2. Image Lab version 5.2 .1 build11

\section{Procedure}

A. Soil sample Collection

1. Dig the soil surface up to $3 \mathrm{~cm}$ depth. Top soil is a precious natural resource as it contains humus (a rich source of nutrients), minerals required for growth of plants and microbial flora. Top soil is mainly rich in microbial diversity. The guidelines for Soil sampling depth is given in Table 1.

Table 1. The guidelines for sampling depth (Fery et al., 2018) and Reference 13

\begin{tabular}{ll}
\hline Crop & Sampling depth $(\mathrm{cm})$ \\
\hline Grasses and grasslands & Up to $5 \mathrm{~cm}$ \\
Shallow rooted crops (e.g., rice, groundnut) & Up to $15 \mathrm{~cm}$ \\
Deep-rooted (e.g., Cotton, sugarcane) & Up to $22 \mathrm{~cm}$ \\
\hline
\end{tabular}

2. Collect three soil samples at different spots (at a distance of $3 \mathrm{~m}$ ) from the same field.

3. Collect the soil in labeled sterile $50 \mathrm{ml}$ Falcons with the help of sterile spatula.

4. Sieve the soil sample with the help of $0.22 \mathrm{~mm}$ mesh.

5. Mix the sieved soil sample.

6. Aliquot 10,000-15,000 mg of above-mixed soil in $50 \mathrm{ml}$ sterile Falcons (maximum 15,000 mg, i.e., one aliquot is enough to carry out all soil DNA extraction methods).

7. Store it in $-20^{\circ} \mathrm{C}$ for long term storage.

B. Soil sample processing

Two types of processing carried out for each method mentioned below: liquid nitrogen grinding and direct.

Note: Clean mortar and pestle with $100 \%$ ethanol.

1. Soil sample 1 (S1): Soil sample processed by using Liquid Nitrogen.

a. Weigh $10,000 \mathrm{mg}$ of the soil sample. 
b. In mortar with pestle, grind the soil sample by carefully pouring liquid nitrogen. The treatment should be continued until it turns in to powder (label this soil sample as S1). The soil sample processed with liquid nitrogen will be used for all the conventional methods listed below. Since $1 \mathrm{~g}$ of soil harbor $10^{10}$ bacterial cells and $4 \times 10^{3}$ to $5 \times 10^{4}$ species diversity, each method requires $500 \mathrm{mg}$ to $1 \mathrm{~g}$ of soil sample (Raynaud and Nunan, 2014).

2. Soil sample 2 (S2): Direct: Without liquid nitrogen processing. The soil sample processed without liquid nitrogen will be used for all the conventional and kit-based methods listed below:

a. Weigh $10,000 \mathrm{mg}$ of the soil sample.

b. In mortar with pestle, grind it without liquid Nitrogen to make powder as fine as possible. Notes:

1. The following methodology is carried out for both samples, i.e., S1 as well as S2, except for kit-based method where only $\mathrm{S} 2$ is used.

2. After extraction of DNA by different methods, immediately store it at $-20^{\circ} \mathrm{C}$.

C. Protocols for total soil DNA extraction

Figure 1 summarizes the above procedure and total soil DNA extraction methods 1 to 8 .

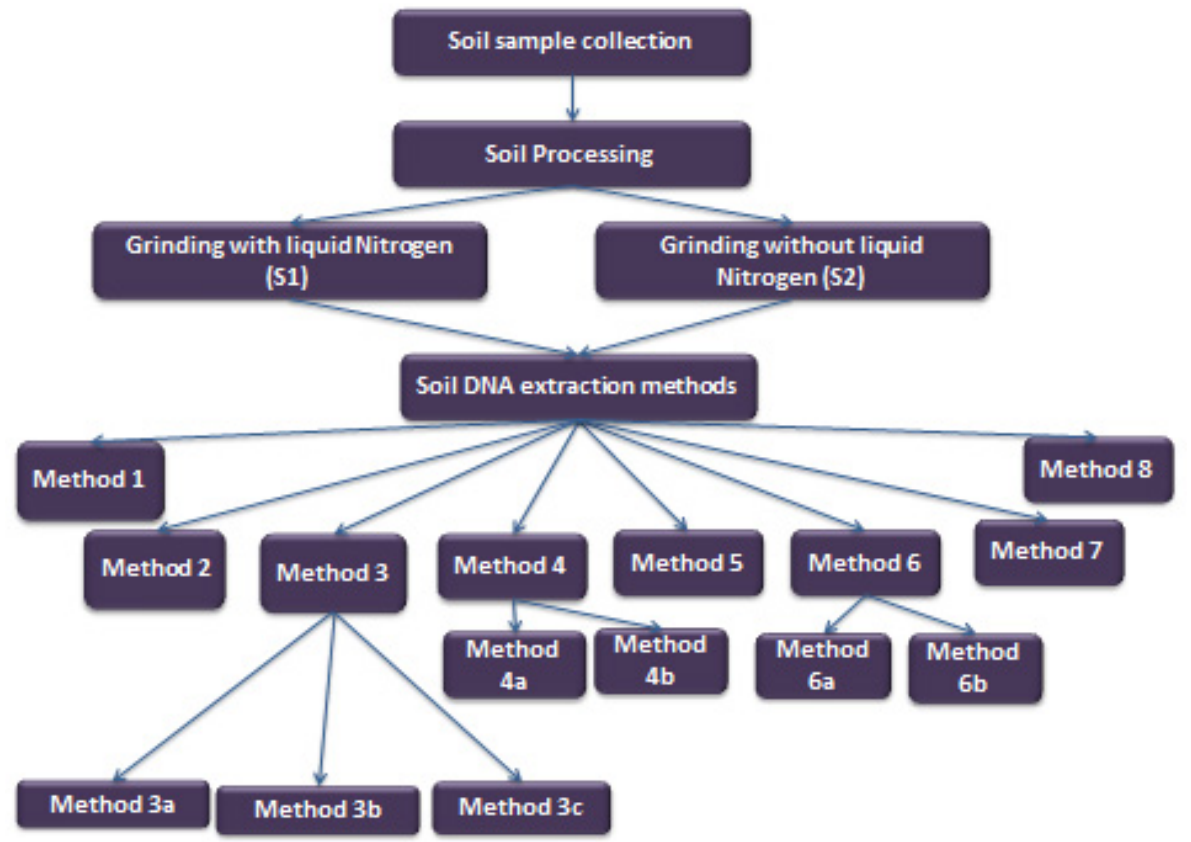

Figure 1. Workflow of soil DNA extraction protocol. The details of different steps and methods 1-8 are described under Methods section.

1. Method 1: PEG Method

a. Weigh $1,000 \mathrm{mg}$ of the soil sample in a $50 \mathrm{ml}$ sterile centrifuge tube and add $10 \mathrm{ml}$ of DNA extraction buffer 1 .

b. Incubate it at $65^{\circ} \mathrm{C}$ for $1 \mathrm{~h}$. in a water bath. 
c. Centrifuge it at $7,000 \times g 10 \mathrm{~min}$ at $4{ }^{\circ} \mathrm{C}$.

d. Collect the supernatant in another centrifuge tube.

e. Add $1 / 2$ volume $50 \%$ PEG (6000) and 1 volume $0.6 \mathrm{M} \mathrm{NaCl}$ (e.g., if the volume of supernatant collected is $5 \mathrm{ml}$, then add $2.5 \mathrm{ml}$ of $50 \%$ PEG (6000) and $5 \mathrm{ml}$ of $0.6 \mathrm{M} \mathrm{NaCl}$ ). Mix the solution gently by inverting the tubes 3-4 times.

f. Add 1 volume of Chloroform:isoamylalcohol (24:1). Mix the solution gently by inverting the tubes 3-4 times.

g. Centrifuge at $13,000 \times g 10 \mathrm{~min}$ at $4{ }^{\circ} \mathrm{C}$.

h. Collect the supernatant.

i. Add 1/10th volume of $3 \mathrm{M}$ sodium acetate $(\mathrm{pH} 5.2)$.

j. Add 2 volumes of ice-cold ethanol (100\%). Mix the solution gently by inverting tubes $3-4$ times. Incubate overnight at $-20^{\circ} \mathrm{C}$, which results in high yield of DNA.

k. Centrifuge at $13,000 \times g 10 \mathrm{~min}$ at $4{ }^{\circ} \mathrm{C}$.

I. Remove the ethanol and air dry the pellet for 15-20 min.

$\mathrm{m}$. Dissolve the pellet in $100 \mu \mathrm{l}$ of $\mathrm{T}_{10} \mathrm{E}_{1}$ buffer.

2. Method 2: Phenol:Chloroform:Isoamylalcohol (PCl) method

a. Follow Steps C1a-C1d of the Method 1.

b. Add equal volume of Phenol:Chloroform:Isoamylalcohol $(25: 24: 1)$ to the supernatant. Mix the solution gently by inverting the tubes 3-4 times.

c. Centrifuge $13,000 \times g 10 \mathrm{~min}$ at $4^{\circ} \mathrm{C}$.

d. Collect the aqueous fraction.

e. Add 2 volumes of ice-cold ethanol and 1/10th volume of $3 \mathrm{M}$ sodium acetate ( $\mathrm{pH}$ 5.2). Mix the solution gently by inverting tubes $3-4$ times. Incubate overnight at $-20^{\circ} \mathrm{C}$.

f. Centrifuge at $13,000 \times \mathrm{g} 10 \mathrm{~min}$ at $4{ }^{\circ} \mathrm{C}$.

g. Remove the supernatant.

h. Air dry the pellet up to $15-20$ min to remove ethanol.

Note: Ethanol can hinder in downstream applications. Hence it is necessary to remove it completely. Be careful not to dry pellet completely.

i. Dissolve the pellet in $100 \mu \mathrm{l}$ of $\mathrm{T}_{10} \mathrm{E}_{1}$ buffer.

3. Method 3

Note: In this method there are three sub-methods naming it as $3 a, 3 b$ and $3 c$. However, steps 'C3a to C3g' are common to all three methods.

a. Weigh $1,000 \mathrm{mg}$ of the soil sample in a $50 \mathrm{ml}$ sterile centrifuge tube and add $5 \mathrm{ml}$ of 120 mM Phosphate Buffer Saline (PBS, pH 7.4).

b. Shake the mixture at $150 \mathrm{rpm} 10 \mathrm{~min}$ at $4{ }^{\circ} \mathrm{C}$ in Hexatech shaker.

c. Centrifuge at $7,000 \times \mathrm{g}$ for $10 \mathrm{~min}$ at $4{ }^{\circ} \mathrm{C}$.

d. Discard the supernatant and wash the pellet with PBS.

e. Again, centrifuge at $7,000 \times g$ for $10 \mathrm{~min}$ at $4{ }^{\circ} \mathrm{C}$.

f. Discard the supernatant and suspend the pellet in $10 \mathrm{ml}$ DNA extraction buffer 2 . 
g. Incubate at $65^{\circ} \mathrm{C}$ for $1 \mathrm{~h}$.

i. Method 3a: Mannitol-PBS-PEG/NaCl

1) Follow Steps $\mathrm{C} 3 a$ to $\mathrm{C} 3 \mathrm{~g}$.

2) Centrifuge the soil suspension at $8,000 \times \mathrm{g} 10 \mathrm{~min}$ at $4{ }^{\circ} \mathrm{C}$.

3) Collect the supernatant.

4) Add $1 / 2$ volume PEG (50\%) and 1 volume of $0.6 \mathrm{M} \mathrm{NaCl}$.

5) Incubate at $4{ }^{\circ} \mathrm{C}$ overnight.

6) Centrifuge at $13,000 \times \mathrm{g} 4{ }^{\circ} \mathrm{C} 10 \mathrm{~min}$.

7) Discard the supernatant and resuspend the pellet in $3 \mathrm{ml}$ TE buffer.

8) Proceed with Steps $C 2 b$ to $C 2 i$.

ii. Method 3b: Mannitol-PBS-PCI

1) Follow Steps $\mathrm{C} 3 \mathrm{a}$ to $\mathrm{C} 3 \mathrm{~g}$.

2) Centrifuge the soil suspension at $7000 \times \mathrm{g} 10 \mathrm{~min}$ at $4{ }^{\circ} \mathrm{C}$.

3) Collect the supernatant.

4) Proceed with Steps $C 2 b$ to $C 2 i$.

iii. Method 3c: Mannitol-PBS-CTAB

1) Follow Steps $\mathrm{C} 3 \mathrm{a}$ to $\mathrm{C} 3 \mathrm{~g}$.

2) Centrifuge the soil suspension at $7,000 \times g 10 \mathrm{~min}$ at $4{ }^{\circ} \mathrm{C}$.

3) Collect the supernatant.

4) Add $50 \mu \mathrm{l} 1 \mathrm{M} \mathrm{NaCl}$ and $50 \mu \mathrm{l} 10 \% \mathrm{CTAB}$ (prepared in $0.6 \mathrm{M} \mathrm{NaCl}$ ).

5) Incubate for $15 \mathrm{~min}$ at $4{ }^{\circ} \mathrm{C}$.

6) Proceed with Steps $\mathrm{C} 2 \mathrm{~b}$ to $\mathrm{C} 2 \mathrm{i}$.

4. Method 4

Note: There are 2 sub-methods of method 4: $4 a$ and $4 b$. Steps 'C4a-C4r' are common for both methods.

a. Weigh $500 \mathrm{mg}$ of soil and add $1 \mathrm{ml}$ of TEN buffer (Tris-Cl-EDTA-NaCl buffer).

b. Vortex for $1 \mathrm{~min}$.

c. Centrifuge at $10,000 \times g 10$ min RT.

d. Decant the supernatant and wash the pellet with $1 \mathrm{ml}$ TEN.

e. Centrifuge at $10,000 \times g 10 \mathrm{~min}$ RT.

f. Discard the supernatant. Resuspend the pellet in $1 \mathrm{ml}$ TEN (add $0.2 \mathrm{mg}$ lysozyme) (see Recipe: TEN buffers supplied with $0.2 \mathrm{mg}$ Lysozyme).

g. Incubate for $1 \mathrm{~h}$ at $37^{\circ} \mathrm{C}$.

h. Keep it on ice for $10 \mathrm{~min}$ and then $20 \mathrm{~min}$ at $65^{\circ} \mathrm{C}$.

i. Add $100 \mu \mathrm{l}$ of $20 \%$ SDS.

j. Vortex for $1 \mathrm{~min}$.

k. Incubate for $30 \mathrm{~min}$ at RT.

I. Centrifuge at $10,000 \times g 10 \mathrm{~min}$ at RT.

m. Collect the supernatant. 
n. Add $500 \mu$ of $3 \mathrm{M}$ sodium acetate.

o. Incubate for $5 \mathrm{~min}$ at $65^{\circ} \mathrm{C}$.

p. Incubate on ice for $20 \mathrm{~min}$.

q. Centrifuge at maximum ' $14,000 \times g^{\prime}$ for 30 min at $4{ }^{\circ} \mathrm{C}$.

r. Collect the supernatant

i. Method 4a

1) Follow Steps C4a-C4r.

2) Proceed with $C 2 b$ to $C 2 i$.

ii. Method $4 \mathrm{~b}$

1) Follow Steps $\mathrm{C} 4 \mathrm{a}-\mathrm{C} 4 \mathrm{r}$.

2) Load the supernatant on Invitrogen PureLink Genomic DNA mini kit spin column.

3) Centrifuge at $16,000 \times g 2 \mathrm{~min}$ RT.

4) Discard the flow-through.

5) Add $500 \mu \mathrm{l}$ of wash buffer 1 into the column.

6) Centrifuge at $16,000 \times g 1 \mathrm{~min}$ RT.

7) Discard the flow-through.

8) Add $500 \mu \mathrm{l}$ of wash buffer2.

9) Centrifuge at $16,000 \times g 1 \mathrm{~min}$ RT.

10) Discard the flow-through.

11) Centrifuge at $18,407 \times g 3 \min R T$.

12) Discard the collection tube.

13) Place column in new sterile $1.5 \mathrm{ml}$ Eppendorf.

14) Add $50 \mu \mathrm{l}$ of elution buffer.

15) Incubate for $2 \mathrm{~min}$ at RT.

16) Centrifuge at $18000 \times g 2$ min at RT.

17) Store at $-20^{\circ} \mathrm{C}$.

5. Method 5

a. Weigh $1,000 \mathrm{mg}$ of soil sample and add $400 \mu \mathrm{l}$ of $50 \mathrm{mM}$ Tris- $\mathrm{HCl}$ and $1 \mathrm{mM}$ EDTA.

b. To the above mixture add 4 sterile glass beads $(2.5 \mathrm{~mm})$.

c. Vortex for 1 min until it is homogenized.

d. Remove glass beads with sterile tweezer.

e. Add $50 \mu$ l lysozyme $(10 \mathrm{mg} / \mathrm{ml})$ (see Recipe: Lysozyme $(10 \mathrm{mg} / \mathrm{ml})$ )

f. Incubate it for $1.5 \mathrm{~h}$. at $37^{\circ} \mathrm{C}$.

g. Add $250 \mu \mathrm{l}$ of Guanidine Hydrochloride (4 M).

h. Mix gently for $45 \mathrm{~s}$.

i. Add $300 \mu$ l Sodium Lauryl Sarcosine.

j. Vortex for $10 \mathrm{~min}$ at $37^{\circ} \mathrm{C}$.

k. Incubate for $1 \mathrm{~h}$ at $70^{\circ} \mathrm{C}$.

I. Add around $300 \mathrm{mg} 0.1 \mathrm{~mm}$ zirconia beads. 
m. Vortex for $20 \mathrm{~min}$.

n. Add $15 \mathrm{mg}$ PVPP.

o. Gently vortex it.

p. Centrifuge at $14,000 \times g 4{ }^{\circ} \mathrm{C}$ for $5 \mathrm{~min}$.

q. Transfer the supernatant in another tube.

r. Wash the pellet with $200 \mu \mathrm{l}$ TENP. Centrifuge at $14,000 \times g{ }^{\circ} \mathrm{C}$ for $5 \mathrm{~min}$. Collect the supernatant carefully.

s. Pool supernatant of Steps C5q-C5r.

t. Add 2 volumes of $100 \%$ ethanol.

u. Invert the tubes

v. Incubate at RT for $5 \mathrm{~min}$.

w. Centrifuge at $14,000 \times g 4^{\circ} \mathrm{C}$ for $5 \mathrm{~min}$.

$x$. Remove the supernatant.

y. Air dry for $15 \mathrm{~min}$.

z. Resuspend the pellet with $450 \mu \mathrm{l}$ of PB supplemented with $50 \mu \mathrm{l} 3 \mathrm{M}$ sodium acetate.

aa. Incubate at $4{ }^{\circ} \mathrm{C}$ for $1 \mathrm{~h}$.

bb. Add $2 \mu$ leach of RNase and Proteinase K.

cc. Incubate for $30 \mathrm{~min}$ at $37^{\circ} \mathrm{C}$.

dd. Add $50 \mu \mathrm{l}$ of sodium acetate $(3 \mathrm{M})$ and $1 \mathrm{ml}$ ethanol.

ee. Centrifuge at $14,000 \times g 10 \min 4^{\circ} \mathrm{C}$.

ff. Remove supernatant and wash pellet with $70 \%$ ice-cold ethanol.

gg. Air dry the pellet.

hh. Resuspend pellet in $100 \mu$ of TE buffer.

6. Method 6

Note: There are 2 sub-methods of method 6: $6 a$ and 6b. Steps 'C6a-C6n' are common for both methods.

a. Weigh $1,000 \mathrm{mg}$ of soil.

b. Add $100 \mathrm{mM}$ sodium phosphate buffer $(\mathrm{pH} 8)$.

c. Add $1 \mathrm{ml}$ of lysozyme solution (see Recipes section below: Lysozyme solution).

d. Incubate at $37^{\circ} \mathrm{C}$ for $2 \mathrm{~h}$.

e. Add $1 \mathrm{ml}$ of SDS solution (see Recipes section below: SDS solution: $10 \%$ SDS $+1 \mathrm{M} \mathrm{NaCl}$ + Tris-HCl).

f. Mix the above mixture well.

g. Incubate it at RT for $5 \mathrm{~min}$.

h. Incubate it on ice for $2 \mathrm{~min}$.

i. Keep it at $65^{\circ} \mathrm{C}$ for $20 \mathrm{~min}$

j. Again on ice for $2 \mathrm{~min}$.

k. Add $1 \mathrm{ml}$ of $3 \mathrm{M}$ sodium acetate.

I. Vortex vigorously. 
$\mathrm{m}$. Centrifuge at $6,000 \times g$ for $10 \mathrm{~min}$.

n. Collect the supernatant.

i. Method 6a

1) Follow Steps C6a-C6n.

2) Proceed with $C 2 b$ to $C 2 i$.

ii. Method 6b

1) Follow Steps C6a-C6n.

2) Add equal volume of ethanol.

3) Centrifuge at $14,000 \times g 10 \mathrm{~min}$ at $4{ }^{\circ} \mathrm{C}$.

4) Remove supernatant.

5) Air dry the pellet.

6) Resuspend the pellet in $100 \mu \mathrm{l}$ TE buffer.

7. Method 7: HiPura soil DNA kit

Weigh $250 \mathrm{mg}^{*}$ of soil and follow manufacturer's instructions given in the manual. The procedure is briefly explained here. The steps and its importance of soil DNA extraction by using HiPurA soil DNA kit are also listed below.

*Note: If it is the sediment sample, then weigh approximately $500 \mathrm{mg}$. Yield of total soil DNA depends upon the sample type and number of micro-organisms present in the sample.

a. Cell lysis

Bead beating and soil lysis solution (SL), along with vigorous vortexing for $10 \mathrm{~min}$, can help in lysing the microbial cells. Separation of the soil particles from lysed microbial cells is done by centrifugation at $13,000 \times g$ for $1 \mathrm{~min}$. Collect the supernatant, and if there are still few soil particles in the collected supernatant, again centrifuge it at $13,000 \times g$ for $1 \mathrm{~min}$ and collect the supernatant.

b. Removal of inhibitors

Add Inhibitor Removal Solution (IRSH) to remove inhibitors such as humic acid. Collect the supernatant; which has nucleic acid, proteins, and other lysed cellular components; by performing a round of centrifugation at $10,000 \times g$ for $1 \mathrm{~min}$. Supernatant should be transparent (brownish color of supernatant indicates high humic acid content) and free of soil particles, otherwise it will hinder in purification steps by clogging the membrane.

c. Purification and elution

Apply the collected supernatant on to spin column to purify total genomic DNA with the aid of silica membrane (present in the spin column format) by using binding, washing and elution buffers. Binding buffer provides optimum $\mathrm{pH}$ environment for nucleic acids to bind on to silica membrane, washing buffers helps to remove proteins and other contaminants, and elution buffer efficiently elute total soil DNA.

8. Method 8: Dneasy Power Soil

Weigh $250 \mathrm{mg}$ of soil and follow manufacturer instructions given in the manual. Briefly the steps and its importance of soil DNA extraction by using Dneasy Power Soil is given below. 
a. Cell lysis

Total soil DNA is extracted by lysis of microbial cells via cell lytic buffer and bead beating method. Hence mechanical and chemical methods are used to obtain efficient cell lysis of microbial cells. Separation of the soil particles from lysed microbial cells is done by centrifugation at $10,000 \times g$ for $30 \mathrm{~s}$. Collect the supernatant, and if there are still few soil particles in the collected supernatant, again centrifuge it at $10,000 \times g$ for $1 \mathrm{~min}$ and collect the supernatant.

b. Removal of inhibitors

Add inhibitor removal solution to remove inhibitors present. Solution should be transparent. Brownish-yellow color solution is a visual indication of the presence of humic acid. Hence solution should be preferably transparent and free of soil particles otherwise it will lead to inefficient extraction of DNA.

c. Purification and Elution of genomic DNA

It is performed by using silica-coated spin column by following number of steps which involves addition of binding buffer in order to bind nucleic acid to the membrane, washing buffers to remove other contaminants such as proteins and elution buffer for eluting total genomic DNA.

D. Visualization of extracted total soil DNA

Prepare $0.8 \%$ gel

1. Weigh $800 \mathrm{mg}$ of Agarose.

2. Dissolve it in $100 \mathrm{ml}$ of $1 \times \mathrm{XAE}$.

3. Microwave it for $2 \mathrm{~min}$ till it is completely dissolved.

4. Let it be warm and add $4 \mu \mathrm{l}$ of $\mathrm{EtBr}(10 \mathrm{mg} / \mathrm{ml})$.

5. Pour it in a casting tray and allow it to solidify.

6. Take $5 \mu \mathrm{l}$ of the extracted DNA $+2 \mu \mathrm{l} 6 \mathrm{x}$ gel loading dye. Mix it well.

7. Load it on the gel.

8. Load $1 \mathrm{kbp}$ ladder and lambda DNA Hindlll digest.

9. Let it resolved in $1 \times$ TAE at 100 volts for $45 \mathrm{~min}$.

10. Visualize it in Gel Documentation system and Image Lab software. The gel images of total soil DNA that was extracted by using Methods 1 to 3,4 to 6,7 and 8 are shown in Figures 2, 3, 4, and 5 respectively. 


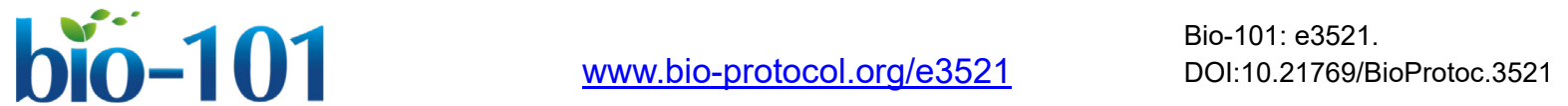

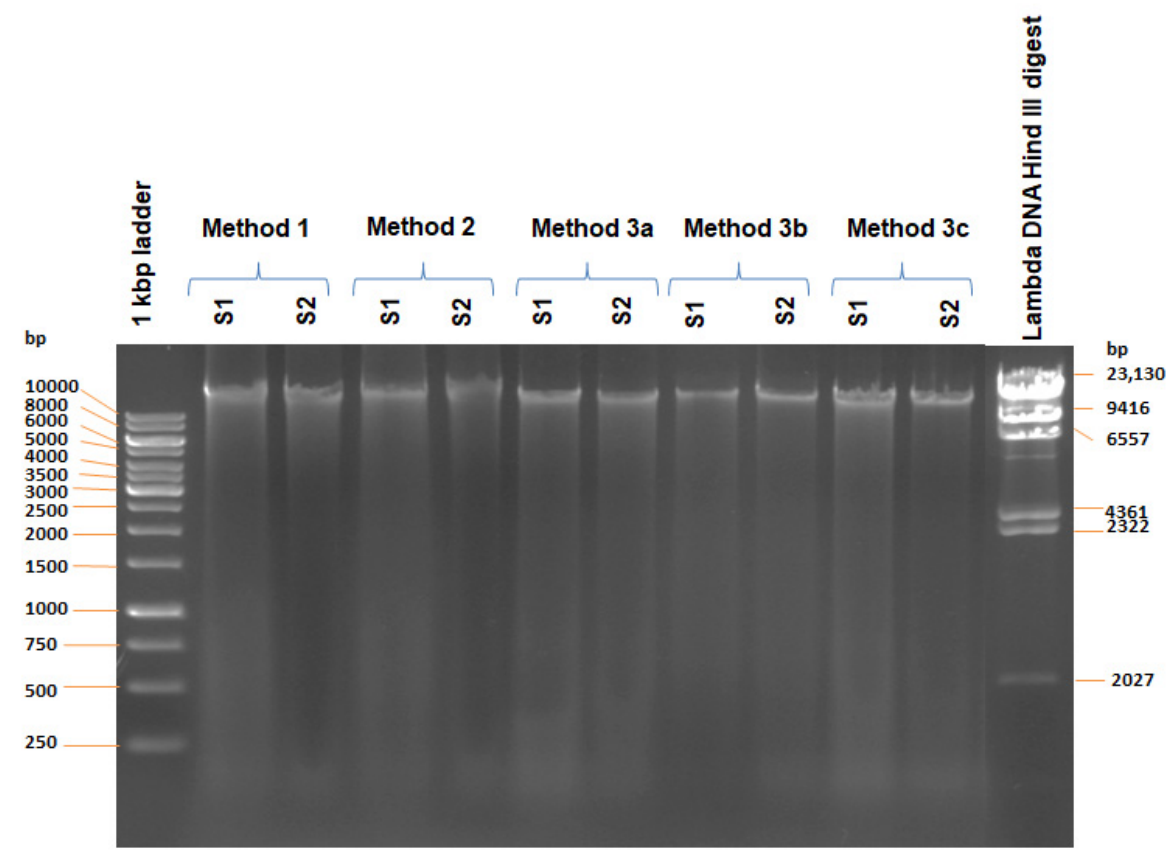

Figure 2. Gel electrophoresis of total soil DNA. The total soil DNA extracted by using methods 1 to 3 were resolved by $0.8 \%$ agarose gel electrophoresis and visualized with the help of Gel Documentation system and Image Lab software. S1: sample processed with liquid nitrogen, S2: sample processed without liquid nitrogen.

Note: High molecular weight DNA (approximately $23 \mathrm{kbp}$ ) was extracted using Methods 1 to 3.

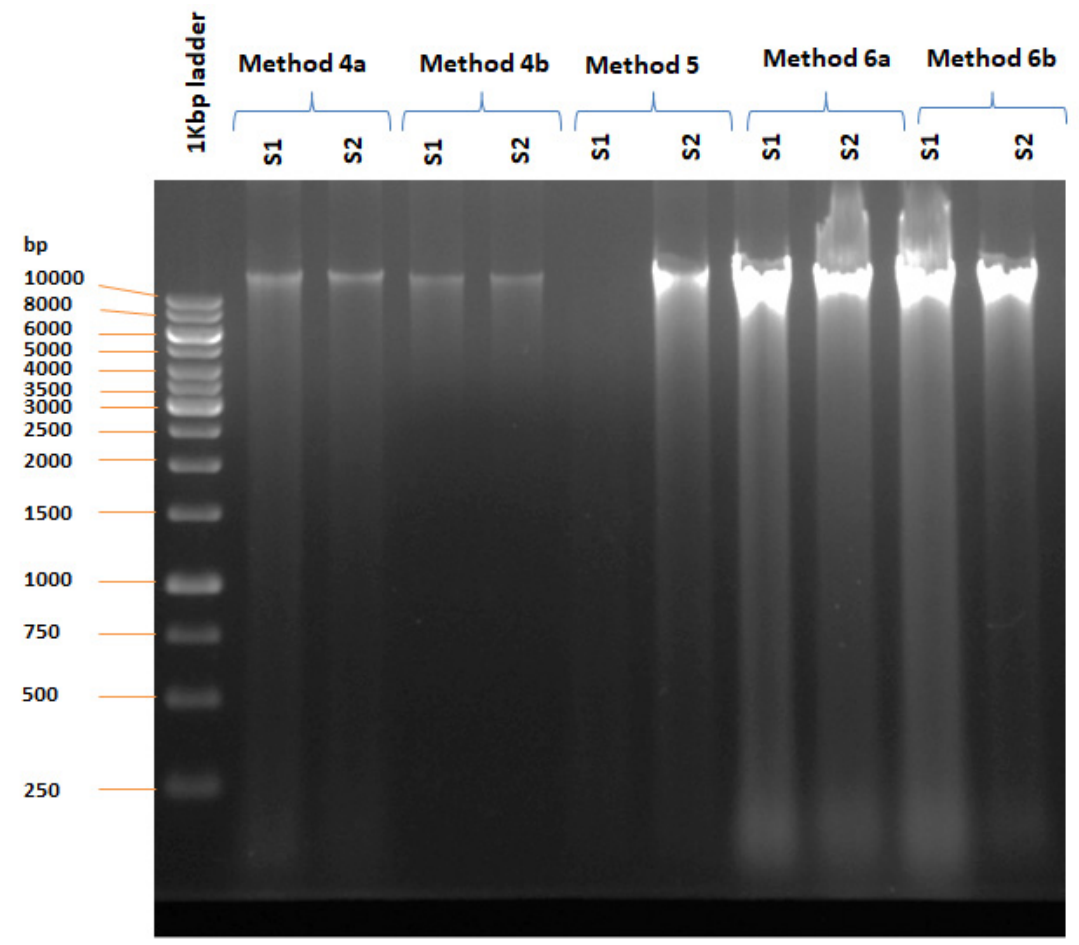

Figure 3. Gel electrophoresis of total soil DNA. The total soil DNA extracted by using methods 4 to 6 were resolved by $0.8 \%$ agarose gel electrophoresis and visualized with the help 
of Gel Documentation system and Image Lab software. S1: sample processed with liquid nitrogen, S2: sample processed without liquid nitrogen.

Note: High molecular weight DNA (>10 kbp) was extracted using Methods 4 to 6 .

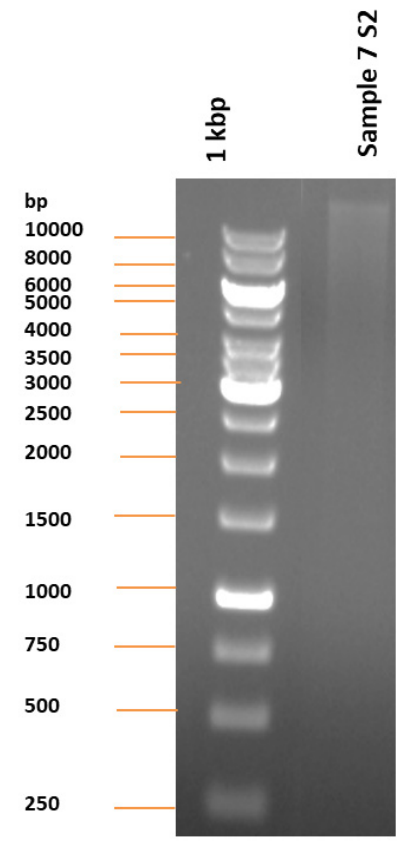

Figure 4. Gel electrophoresis of total soil DNA. The total soil DNA extracted by using method 7 were resolved by $0.8 \%$ agarose gel electrophoresis and visualized with the help of Gel Documentation system and Image Lab software. S1: sample processed with liquid nitrogen, S2: sample processed without liquid nitrogen.

Note: High molecular weight DNA (> $10 \mathrm{kbp}$ ) was extracted using Method 7. 


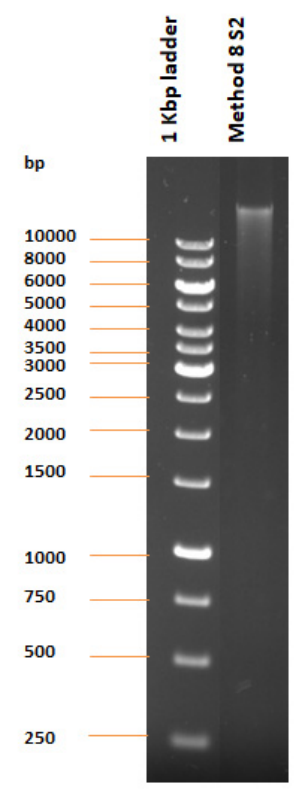

Figure 5. Gel electrophoresis of total soil DNA. The total soil DNA extracted by using method 8 were resolved by $0.8 \%$ agarose gel electrophoresis and visualized with the help of Gel Documentation system and Image Lab software. S1: sample processed with liquid nitrogen, S2: sample processed without liquid nitrogen.

Note: High molecular weight DNA (>10 kbp) was extracted using Method 8.

E. BioTek Epoch Microplate spectrophotometer

1. Clean Take-3 plate reader with ethanol.

2. Dilute the samples if necessary (1:100 or 1:200 dilution) by using elution buffer as diluent.

3. Blank should be elution buffers used for different extraction procedures.

4. Add $2 \mu \mathrm{l}$ on the plate and read it with the help of BioTek ELISA plate and support by Gen 5 Software for providing user-friendly interface for analysis. The quantification of total soil DNA is collectively shown in Table 2 and Figure 6. 
Table 2. Quantification of total soil DNA using BioTek Epoch Microplate spectrophotometer

\begin{tabular}{llll}
\hline Sample & $\mathrm{ng} / \mathrm{\mu l}$ & $\mathrm{A}_{260} / \mathrm{A}_{280}$ & $\mathrm{~A}_{260} / \mathrm{A}_{230}$ \\
\hline Method 1 S1 & 9217.8 & 1.438 & 0.534 \\
Method 1 S2 & 6380.6 & 1.487 & 0.482 \\
Method 2 S1 & 4277.8 & 1.478 & 0.577 \\
Method 2 S2 & 6003.4 & 1.46 & 0.616 \\
Method 3a S1 & 3704.6 & 1.534 & 1.174 \\
Method 3a S2 & 5767.7 & 1.458 & 1.416 \\
Method 3b S1 & 6576.6 & 1.516 & 0.711 \\
Method 3b S2 & 2814 & 1.515 & 0.627 \\
Method 3c S1 & 4298 & 1.472 & 0.626 \\
Method 3c S2 & 4601.7 & 1.507 & 0.677 \\
Method 4a S1 & 856.3 & 1.19 & 0.689 \\
Method 4a S2 & 681.2 & 1.442 & 0.745 \\
Method 4b S1 & 34.1 & 2.33 & 0.048 \\
Method 4b S2 & 14.8 & 3 & 0.023 \\
Method 5a S1 & 104 & 2.33 & 0.184 \\
Method 5a S2 & 563.8 & 1.468 & 0.649 \\
Method 6a S1 & 616.9 & 1.732 & 0.691 \\
Method 6a S2 & 1825.8 & 1.604 & 1.433 \\
Method 6b S1 & 1567.5 & 1.699 & 1.427 \\
Method 6b S2 & 453.1 & 1.561 & 1.391 \\
Method 7 S2 & 11.045 & 1.851 & 1.052 \\
Method 8 S2 & 19.608 & 1.87 & 1.789 \\
\hline & & & \\
\hline
\end{tabular}




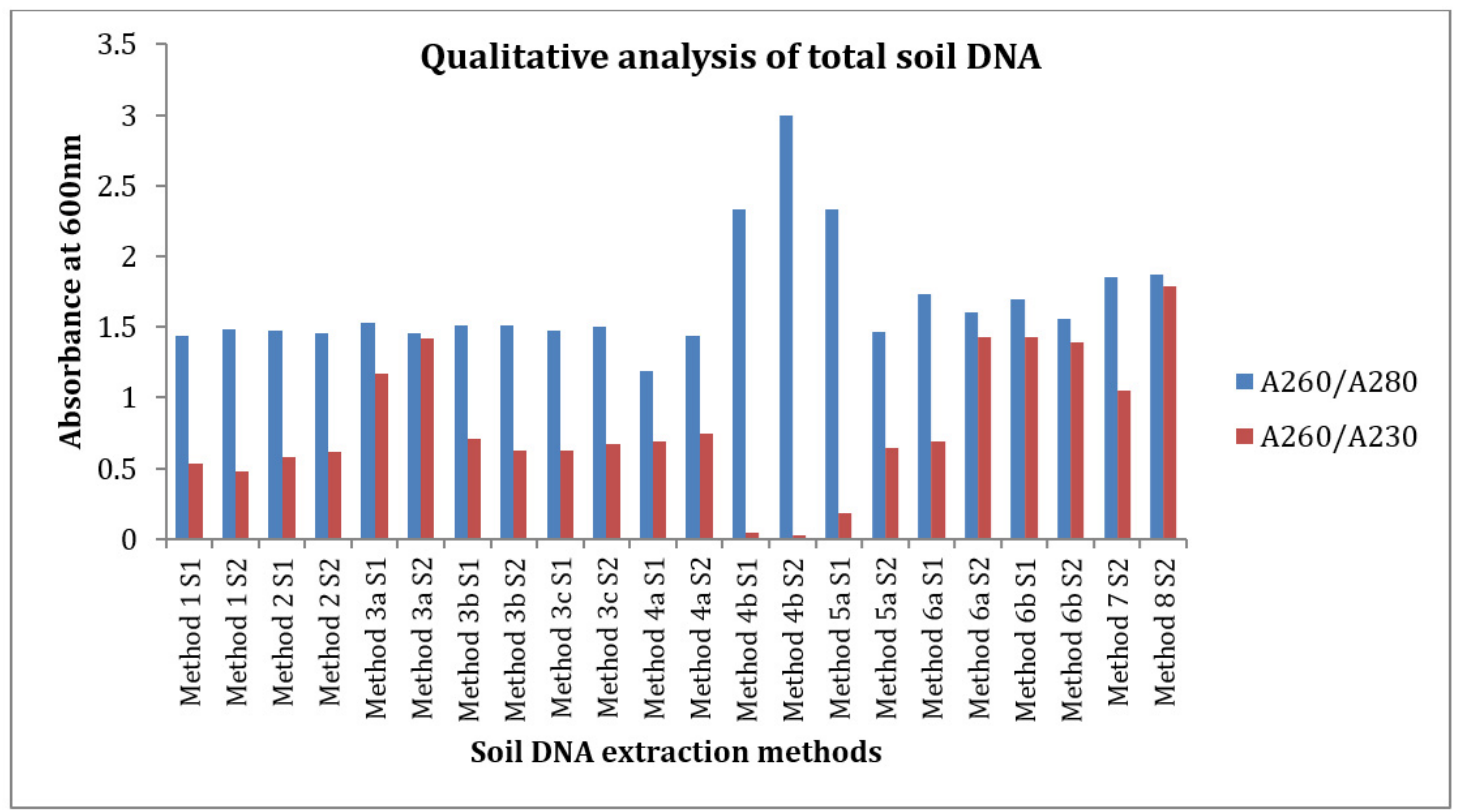

Figure 6. Qualitative analysis of total soil DNA: $A$ ratio of $A_{260} / A_{280}$ and $A_{260} / A_{230}$ indicates the quality of extracted DNA. If the ratio of $A_{260} / A_{280}$ is in between 1.8 and 2 , it indicates high quality DNA. If it is less than 1.8 , it indicates protein or other aromatic compounds contamination. If the ratio of $A_{260} / A_{230}$ is less than 2 it indicates the presence of organic components such as humic acid. Humic acid present in soil samples can co-extract with the total soil DNA during the extraction procedure since both have the same charge and characteristics. Humic acid has the ability to interfere in downstream applications such as PCR (Humic acid binds to DNA polymerase and interfere in its activity) (Fatima et al., 2014)

Conclusion: In the present study, conventional as well commercial kit based methods were used to extract total genomic DNA from soil. The quality and quantity of the extracted total DNA were visualized and analyzed by using the BioTek Epoch Microplate spectrophotometer $\left(A_{260} / A_{280}\right.$ and $A_{260} / A_{230}$ ratio) and Gel electrophoresis technique. Commercial kit-based methods aid to obtain high quality of DNA as compare to conventional methods. Soil DNA extraction is the first step to explore culturable (accounts for $1 \%$ of microbial communities) as well as non-culturable microbial diversity (accounts for rest $99 \%$ of microbial communities) in a given soil sample. The DNA extracted by above-mentioned protocols can be used to perform soil metagenomics studies in order to discover novel biomolecules such as novel metabolites, enzymes, antibiotics (Kapoor et al., 2015; Farias et al., 2018; Castillo Villamizar et al., 2019). It can also be used to study microbial diversity in different soil samples using 16S rRNA gene metagenomics. This will expand the existing microbial databases and also help to understand the effect of various environmental factors on soil microbial population and diversity (Leite et al., 2014; Liu et al., 2019; Matsushita et al., 2019). 


\section{Recipes}

A. Stock solution

1. $1 \mathrm{M} \mathrm{NaCl}$

a. Add $2,922 \mathrm{mg}$ of $\mathrm{NaCl}$ in $40 \mathrm{ml}$ of MilliQ-water and then make up the volume to $50 \mathrm{ml}$ with MilliQ-water

b. Store at RT

2. $1 \mathrm{M} \mathrm{NaH}_{2} \mathrm{PO}_{4}$

a. Weigh $7,800.5 \mathrm{mg}$ in $40 \mathrm{ml}$ of MilliQ-water. Mix well. Make up the volume to $50 \mathrm{ml}$ with MilliQ-water

b. Store at RT

3. $1 \mathrm{M} \mathrm{Na}_{2} \mathrm{HPO}_{4}$

a. Add 7,080 mg of $\mathrm{Na}_{2} \mathrm{HPO}_{4}$ in $40 \mathrm{ml}$ of MilliQ-water. Mix well. Make up the volume to $50 \mathrm{ml}$ with MilliQ-water

b. Store at RT

4. $0.2 \mathrm{M} \mathrm{Na}_{2} \mathrm{HPO}_{4}$

a. Add $4 \mathrm{ml}$ of $1 \mathrm{M} \mathrm{Na}_{2} \mathrm{HPO}_{4}$ in $16 \mathrm{ml}$ of MilliQ-water

b. Store at RT

5. $1 \mathrm{M}$ Tris- $\mathrm{HCl}$
a. Add $7,880 \mathrm{mg}$ of Tris- $\mathrm{HCl}$ in $40 \mathrm{ml}$ of MilllQ-water
b. Adjust the $\mathrm{pH}$ to 8
c. Make the volume to $50 \mathrm{ml}$ with MilliQ-water
d. Store at RT

6. $0.2 \mathrm{M}$ EDTA
a. Add 3,725 mg of EDTA in $30 \mathrm{ml}$ of MilliQ-Water. Keep this mixture on the magnetic stirrer
b. Add few pellets of $\mathrm{NaOH}$ and let it stir until EDTA completely dissolves. Check the $\mathrm{pH}$ of the solution. It should be $\mathrm{pH} 8$ since EDTA dissolves at $\mathrm{pH} 8$
c. Store at RT

7. $1 \mathrm{M} \mathrm{HCl}(1 \mathrm{~L})$

Add $83 \mathrm{ml}$ of concentrated $\mathrm{HCl}$ and adjust the volume to $1 \mathrm{~L}$ with MilliQ-water

8. 50x TAE buffer

$2 \mathrm{M}$ Tris-Base

$1 \mathrm{M}$ Glacial acetic acid

50 mM EDTA

For total volume $1 \mathrm{~L}$ :
a. Add $242,000 \mathrm{mg}$ of Tris-Base
b. Dissolve it in $750 \mathrm{ml}$ of deionized water
c. Carefully add $57.1 \mathrm{ml}$ of Glacial Acetic Acid
d. Add $100 \mathrm{ml}$ of $0.5 \mathrm{M}$ EDTA ( $\mathrm{pH} 8$ ) 
e. Adjust the solution to final volume of $1 \mathrm{~L}$

f. Store at RT

B. Working stock solution

Note: Filter all following preparations with $0.45 \mu \mathrm{m}$ filter.

1. DNA extraction buffer 1

Final concentration: $120 \mathrm{mM} \mathrm{Na}_{2} \mathrm{HPO}_{4}+5 \% \mathrm{SDS}(\mathrm{w} / \mathrm{v})+0.1 \mathrm{~g}$ PVPP)

For $50 \mathrm{ml}$ total volume follow the recipe given below:

a. Add $6 \mathrm{ml}$ of $1,000 \mathrm{mM} \mathrm{Na} 2 \mathrm{HPO}_{4}+0.1 \mathrm{mg}$ PVPP. Mix it well

b. Then add $2,500 \mathrm{mg}$ of SDS. Mix it well and keep it at $50^{\circ} \mathrm{C}$ to completely dissolve

c. Let the froth settle down

d. Make the volume to $50 \mathrm{ml}$ with MilliQ-water

2. $50 \%$ PEG (6000)

For $10 \mathrm{ml}$ total volume

a. Add 5,000 mg of PEG 6000 in $7 \mathrm{ml}$ of MilliQ-water. Dissolve it properly. Keep it at 50-60 ${ }^{\circ} \mathrm{C}$ water bath until dissolve

b. Make the volume to $10 \mathrm{ml}$ with MilliQ-water

3. $0.6 \mathrm{M} \mathrm{NaCl}$

For total volume $25 \mathrm{ml}$

a. Add $15 \mathrm{ml}$ of the $1 \mathrm{M} \mathrm{NaCl}$ in $7 \mathrm{ml}$ of $\mathrm{MilliQ}-\mathrm{H}_{2} \mathrm{O}$

b. Dissolve it by vortexing

c. Make up the volume to $25 \mathrm{ml}$ by using MilliQ-water

4. Chloroform:Isoamyl alcohol (24:1)

For total volume $25 \mathrm{ml}$

a. Add $24 \mathrm{ml}$ of Chloroform in $1 \mathrm{ml}$ of isoamylalcohol

b. Mix it well

c. Store at $4{ }^{\circ} \mathrm{C}$

5. $3 \mathrm{M}$ sodium acetate

Total volume $50 \mathrm{ml}$

a. Add $12,304.5 \mathrm{mg}$ of Sodium acetate in $30 \mathrm{ml}$ of MilliQ-Water

b. Adjust the $\mathrm{pH}$ to 5.2

c. Make up the volume to $50 \mathrm{ml}$ with MilliQ-water

6. $\mathrm{T}_{10} \mathrm{E}_{1}$ buffer

Total volume $50 \mathrm{ml}$

a. Add $0.5 \mathrm{ml}$ of $1 \mathrm{M}$ Tris- $\mathrm{HCl}+0.25 \mathrm{ml}$ of $0.2 \mathrm{M}$ EDTA $+49.25 \mathrm{ml}$ of MilliQ-water

b. Mix it well and store at $4{ }^{\circ} \mathrm{C}$

7. $\mathrm{PCl}$

a. Add Equilibration buffer in to the content as per manufacturer's instructions

b. $\mathrm{pH}$ of the phenolic phase is between 7.8-8.2 
C. Mix it well and store at $4{ }^{\circ} \mathrm{C}$

8. $0.1 \mathrm{M}$ Phosphate buffer saline

$0.02 \mathrm{M} \mathrm{NaH}_{2} \mathrm{PO}_{4}$

$0.08 \mathrm{M} \mathrm{Na}_{2} \mathrm{HPO}_{4}$

$9 \% \mathrm{NaCl}$

For $50 \mathrm{ml}$ total volume:

a. Add $5 \mathrm{ml}$ of $1 \mathrm{M} \mathrm{NaH}_{2} \mathrm{PO}_{4}+20 \mathrm{ml}$ of $0.2 \mathrm{M} \mathrm{Na}_{2} \mathrm{HPO}_{4}+4,500 \mathrm{mg}$ of $\mathrm{NaCl}$

b. Adjust the $\mathrm{pH} 7.4$

c. Make up the volume to $50 \mathrm{ml}$ with MilliQ-water

9. DNA extraction buffer 2

For $10 \mathrm{ml}$ DNA extraction buffer-2:

$0.1 \mathrm{M}$ Tris- $\mathrm{HCl}(\mathrm{pH} 8.0)$

$0.2 \mathrm{M}$ EDTA ( $\mathrm{pH} 8.0)$

$10 \%$ SDS

0.2 M Mannitol

$1 \mathrm{M} \mathrm{NaCl}$

$2 \%$ CTAB

Follow the steps given below:

a. Add $2 \mathrm{ml}$ of $1 \mathrm{M}$ Tris-HCl+ $1 \mathrm{ml}$ of $0.2 \mathrm{M}$ EDTA+ $1 \mathrm{mg}$ SDS

b. Vortex to mix it

c. Keep it at $60^{\circ} \mathrm{C}$ to dissolve the mixture completely

d. Let the foam settle down

e. Add $0.3643 \mathrm{mg}$ mannitol. Dissolve it properly

f. Add $0.2 \mathrm{mg}$ of CTAB. Vortex it vigorously. Again let the foam settles down

g. Keep it at $60^{\circ} \mathrm{C}$ until dissolve

h. Add $0.5 \mathrm{~g}$ of $\mathrm{NaCl}$. Vortex. Again keep it at $60^{\circ} \mathrm{C}$ to dissolve completely

i. Filter the solution through $0.45 \mu \mathrm{m}$ filter

10. $10 \% \mathrm{CTAB}+0.7 \mathrm{M} \mathrm{NaCl}$

For total volume $25 \mathrm{ml}$ :

a. Pre-warm $20 \mathrm{ml}$ of MilliQ-Water

b. Add $2.5 \mathrm{mg}$ of $\mathrm{CTAB}+1.0227 \mathrm{mg} \mathrm{NaCl}$ in pre-warm water

c. Make up the volume to $25 \mathrm{ml}$ with MilliQ-water

11. TEN buffer ( $\mathrm{pH} 8.0)$

$100 \mathrm{mM}$ Tris- $\mathrm{HCl}$

50 mM EDTA

$500 \mathrm{mM} \mathrm{NaCl}$

Add $5 \mathrm{ml}$ of $1 \mathrm{M}$ Tris- $\mathrm{HCl}+12.5 \mathrm{ml}$ of $0.2 \mathrm{M}$ EDTA $+25 \mathrm{ml}$ of $1 \mathrm{M} \mathrm{NaCl}+42.5 \mathrm{ml}$ of MilliQ-water

12. TEN buffers supplied with $0.2 \mathrm{mg}$ Lysozyme

For total volume $1 \mathrm{ml}$ 

a. $1 \mathrm{ml}$ of TEN buffer $+0.2 \mathrm{mg}$ of Lysozyme
b. Vortex it to dissolve
c. Keep it completely in water-sonicator

13. $20 \%$ SDS

For $50 \mathrm{ml}$ total volume

a. Weigh $10,000 \mathrm{mg}$ of SDS. Add it in $45 \mathrm{ml}$ of MilliQ-water

b. Vortex it

c. Keep it at $40{ }^{\circ} \mathrm{C}$ in water bath until dissolve

14. $\mathrm{T}_{50} \mathrm{E}_{1}$

For total volume $5 \mathrm{ml}$

a. Add $0.25 \mathrm{ml}$ of $1 \mathrm{M}$ Tris- $\mathrm{HCl}+0.025 \mathrm{ml}$ of $0.2 \mathrm{M} \mathrm{EDTA}+4.725 \mathrm{MilliQ}$-water

b. Store at RT

15. Lysozyme $(10 \mathrm{mg} / \mathrm{ml})$
a. Weigh $10 \mathrm{mg}$ of Lysozyme in $1 \mathrm{ml}$ of MilliQ-water
b. Vortex it until dissolve

16. Guanidine- $\mathrm{HCl}(5 \mathrm{M})$

For total volume $25 \mathrm{ml}$
a. Weigh $11,941 \mathrm{mg}$ of Guanidine- $\mathrm{HCl}$ in $20 \mathrm{ml}$ of MilliQ-water. Vortex it
b. Make up the volume to $25 \mathrm{ml}$ with MilliQ-water

17. $10 \%$ Sodium Lauryl Sarcosine
a. Weigh $5,000 \mathrm{mg}$ of Sodium Lauryl Sarcosine
b. Add $45 \mathrm{ml}$ of MilliQ-water
c. Make up the volume to $50 \mathrm{ml}$ with MilliQ-water

18. TENP

$50 \mathrm{mM}$ Tris- $\mathrm{HCl}$

20 mM EDTA

$100 \mathrm{mM} \mathrm{NaCl}$

$1 \%$ PVPP

Add $2.5 \mathrm{ml}$ of $1 \mathrm{M}$ Tris- $\mathrm{HCl}+5 \mathrm{ml}$ of $0.2 \mathrm{M}$ EDTA $+5 \mathrm{ml}$ of $1 \mathrm{M} \mathrm{NaCl}$

19. Lysozyme solution

$150 \mathrm{mM}$ Tris- $\mathrm{HCl}$

$100 \mathrm{mM}$ EDTA

Lysozyme $(15 \mathrm{mg} / \mathrm{ml})$

For total volume $25 \mathrm{ml}$ :

a. Add $3.75 \mathrm{ml}$ of $1 \mathrm{M}$ Tris- $\mathrm{HCl}+12.5 \mathrm{ml}$ of $0.2 \mathrm{M}$ EDTA $+375 \mathrm{mg}$ of lysozyme

b. Make up the volume to $25 \mathrm{ml}$ with MilliQ-water

20. SDS solution
a. $1 \mathrm{ml}$ of $1 \mathrm{M} \mathrm{NaCl}+5 \mathrm{ml}$ Tris- $\mathrm{HCl}+1 \mathrm{~g} \mathrm{SDS}(10 \%)$. Mix well
b. Let the foam settle down 
c. Make up the volume to $10 \mathrm{ml}$ with MilliQ-water

21. $1 \times$ TAE buffer $(1 \mathrm{~L})$

Add $20 \mathrm{ml}$ of $50 x$ TAE $+980 \mathrm{ml}$ of MilliQ-water

22. $70 \%$ Ethanol

a. Add $70 \mathrm{ml}$ of $100 \%$ ethanol $+30 \mathrm{ml}$ of MiliQ-water

b. Store at $0{ }^{\circ} \mathrm{C}$

\section{Acknowledgments}

The present study was supported by SVKM's NMIMS intramural seed grant. We would like to acknowledge research papers authored by Fatima et al., 2011 and 2014; Bag et al., 2016.

\section{Competing interests}

The authors declare no conflict of interest.

\section{References}

1. Bag, S., Saha, B., Mehta, O., Anbumani, D., Kumar, N., Dayal, M., Pant, A., Kumar, P., Saxena, S., Allin, K. H., Hansen, T., Arumugam, M., Vestergaard, H., Pedersen, O., Pereira, V., Abraham, P., Tripathi, R., Wadhwa, N., Bhatnagar, S., Prakash, V. G., Radha, V., Anjana, R. M., Mohan, V., Takeda, K., Kurakawa, T., Nair, G. B. and Das, B. (2016). An improved Method for High Quality Metagenomics DNA Extraction from Human and Environmental Samples. Sci Rep 6: 26775.

2. Castillo Villamizar, G. A., Nacke, H., Boehning, M., Herz, K. and Daniel, R. (2019). Functional metagenomics reveals an overlooked diversity and novel features of soil-derived bacterial phosphatases and phytases. MBio 10(1): 10(1):1-15.

3. Fatima, F., Chaudhary, I., Ali, J., Rastogi, S., Pathak, N. (2011). Microbial DNA extraction from soil by different methods and its PCR amplification. Bichem.cell.Arch.

4. Farias, N., Almeida, I. and Meneses, C. (2018). New bacterial phytase through metagenomic prospection. Molecules 23(2):1-14.

5. Fatima, F., Pathak, N. and Rastogi Verma, S. (2014). An improved method for soil DNA extraction to study the microbial assortment within rhizospheric region. Mol Biol Int 2014: 518960.

6. Kapoor, S., Rafiq, A. and Sharma, S. (2017). Protein engineering and its applications in food industry. Crit Rev Food Sci Nutr 57(11): 2321-2329.

7. Lamizadeh, E., Enayatizamir, N. and Motamedi, H. (2019). Difference in some biological properties of saline and non-saline soil under sugarcane cultivation.Soil Biology 52(6): 690-695. 
8. Leite, D. C., Balieiro, F. C., Pires, C.,A., Madari, B. E., Rosado, A. S., Coutinho, H. L. and Peixoto, R. S. (2014). Comparison of DNA extraction protocols for microbial communities from soil treated with biochar. Brazilian J Microbiol 45(1):175-183.

9. Liu, M., Huang, H., Bao, S. and Tong, Y. (2019). Microbial community structure of soils in Bamenwan mangrove wetland. Sci Rep 9(1): 8406.

10. Matsushita, Y., Egami, K. Sawada, A., Saito, M., Sano, T., Tsushima, S. and Yoshida, S. (2019) Analyses of soil bacterial community diversity in naturally and conventionally farmed apple orchards using 16S rRNA gene sequencing. Applied Soil Ecology 141: 26-29.

11. Fery, M., Choate. J. and Murphy, E. (2018). A guide to collecting soil samples for farms and gardens. EC 628.

12. Raynaud, X. and Nunan, N. (2014). Spatial ecology of bacteria at the microscale in soil. PLoS One 9(1): e87217.

13. Resource Management:: Soil:: Soli sampling Procedure. Available at: http://agritech.tnau.ac.in/agriculture/agri soil sampling.html (Accessed: 21 November 2019).

14. Robe, P., Nalin, R., Capellano, C., Vogel, T. M. and Simonet, P. (2003). Extraction of DNA from soil. European Journal of Soil Biology 39(4): 183-190.

15. Satyanarayana, S. D. V., Krishna, M. S. R. and Kumar, P. P. (2017). Optimization of high-yielding protocol for DNA extraction from the forest rhizosphere microbes. 3 Biotech 7(2): 91. 